\title{
COMUNICACIÓN
}

\section{Protozoan parasites in captive chinchillas (Chinchilla lanigera) raised in the State of Rio Grande do Sul, Brazil}

\author{
ANA CLÁUDIA FAGUNDES GURGEL*, AMANDA DOS SANTOS SARTORI** \\ e FLÁVIO ANTÔNIO PACHECO DE ARAÚJO***
}

\begin{abstract}
The aim of the present study was to identify Giardia sp., Eimeria spp. and Cryptosporidium spp. in fecal samples of chinchillas, respectively raised on farms located in the cities of Gravatai and Porto Alegre (State of Rio Grande do Sul, Brazil), Giardia sp. was detected in $8 \%$ of 250 samples. The variables age $(p=0.47)$ and gender $(p=0.07)$, submitted to Fisher's exact test, were not related to the results obtained through the method of Faust et al. (1939) apud Hoffmann (1987). Oocysts of Eimeria spp. and Cryptosporidium spp. were not identified in any of the samples.

Key words: Giardia, Eimeria, Cryptosporidium, chinchillas.
\end{abstract}

\section{INTRODUCTION}

Originally, chinchillas (Chinchilla lanigera) lived in the wild and fed on herbs in the Andean steppes, on tree shells and on leaves from bushes. They used to be a food source for the Chincha indians, as well as a pelt provider ${ }^{1}$.

Chinchillas are circumscribed to the Andean countries, in South America, and can be easily bred in captivity, with a life span of up to 20 years ${ }^{2}$. They have been bred in captivity since the 1920 s and are certainly a commercially profitable venture ${ }^{3}$.

In Brazil, the breeding of chinchillas has demonstrated improved quality and achieved a strong market position. The State of Rio Grande do Sul, in southern Brazil, has 200 commercial breeders ${ }^{4}$.

Giardiosis is the most common and the major parasitic infectious disease of chinchillas ${ }^{1}$. Giardia spp are flagellated protozoans found in the small intestines of mammals, birds, reptiles, and amphibians; they are believed to be the first human intestinal parasite to be identified ${ }^{5}$.

The mature cysts found in the feces are infective and resistant to adverse environmental conditions. Infection of new hosts occurs when these fully developed cysts are ingested with food and water ${ }^{6}$. In water or in a moist, sunlightdeprived environment, the cyst may remain viable for up to two months ${ }^{7}$.

This flagellated protozoan may change from a harmless intestinal parasite to a virulent pathogen that can cause severe debilitation, leaving the host

\footnotetext{
* Veterinary Doctor, Master's Student at PPGCV, Universidade Federal do Rio Grande do Sul (UFRGS).

** Undergraduate Student, School of Veterinary Medicine, UFRGS, and Scholarship Holder of FAPERGS grant.

*** Veterinary Doctor, Professor of Protozoology at UFRGS.

Correspondence to: Ana C. Fagundes Gurgel. Universidade Federal do Rio Grande do Sul (UFRGS).Faculdade de Medicina Veterinária. Av. Bento Gonçalves, 9090. CEP 91540-000. Porto Alegre, RS, Brasil.
} 
susceptible to all kinds of severe illnesses, which eventually result in death ${ }^{8}$.

Giardia lamblia usually becomes pathogenic when chinchillas are under stress, especially in the case of newly weaned offspring or in cases of imbalance of the intestinal flora. Changes in food and water supply, or planer shavings contaminated with feces of other animals, as well as changes in feeding conditions may trigger an outbreak of Giardia spp on a farm ${ }^{4}$. Giardiosis is associated with stressful, overcrowding, and unhygienic conditions which favor the transmission of the parasite?

Cryptosporidium has been recognized from the seventies onwards as the cause of enteritis in turkeys, cattle, in many species of fish and reptiles, and in humans. Cryptosporidium is also the major cause of acute gastroenteritis in immunocompetent patients ${ }^{10}$.

The zoonotic implications of cryptosporidiosis reinforce the fact that the water is the major route of transmission. Maximum control over water sources for consumption constitutes a public health problem ${ }^{11}$.

Yamini and Raju (1986) ${ }^{12}$ described cryptosporidiosis in a chinchilla with severe diarrhea. The histological analysis revealed several spherical structures that are characteristic of Cryptosporidium spp. in the epithelial cells of the stomach, duodenum, jejunum, ileum, and colon.

Eimeriosis is also a contagious enteritis, caused by Eimeria species, which affects the small and/or large intestine, mainly of young animals ${ }^{13}$. Eimeria chinchillae causes watery and hemorrhagic diarrhea, tympanites, and seizures ${ }^{14}$. The host is infected by ingesting sporulated oocysts ${ }^{15}$.

There are no publications about protozoa in chinchillas raised in the state of Rio Grande do Sul. The aim of the present work was to verify the occurrence of Giardia, Eimeria, and Cryptosporidium in chinchillas from commercial farms in the state of Rio Grande do Sul, Brazil, and to assess the positivity for these parasites based on their age and gender.

\section{MATERIAL AND METHODS}

\section{Experimental design and fecal samples:}

The fecal samples were collected from experimental animals on three different commercial farms located in the cities of Gravataí and Porto Alegre, state of Rio Grande do Sul, in southern Brazil, between August 2002 and June 2003. The fecal samples of 250 chinchillas were collected from animals kept in individual cages, and were distributed into two groups according to their ages ( $<12$ months and $\geq 12$ months) and gender.

The samples were stored on ice and taken to the laboratory, where they were maintained in a fridge at $-8^{\circ} \mathrm{C}$ until their analysis.

The study protocol was approved by the local Research Ethics Committee.

\section{Parasitological methods:}

Each sample was processed and evaluated using the methods of Faust et al. (1939) to detect the presence of Giardia; Sheather's method modified by Benbrook (1929) to detect the presence of Eimeria; andZiehl-Neelsen staining method modified by Angus, to detect Cryptosporidium, all of them apud Hoffmann (1987) ${ }^{16}$.

The diagnosis was based on the presence of Giardia cysts and Eimeria and Cryptosporidium oocysts in the feces by means of light microscopy. Statistical analysis.

The results were analyzed using Fisher's exact test and INSTAT statistical package.

\section{RESULTS}

Giardia cysts were detected in $8 \%(20 / 250)$ of the animals. Table 1 presents the $8 \%$ positivity for Giardia sp. in chinchillas with same age and gender. None of the samples analyzed presented oocysts of Eimeria spp. and Cryptosporidium spp.

\section{DISCUSSION}

The present study is the first account of giardiosis in chinchillas in the State of Rio Grande do Sul, in southern Brazil. Although there is no occurrence of giardiosis in chinchillas in Brazil, an $8 \%$ rate is very important, due to its pathogenicity and possibility of transmission to other animals, as well as to humans that are involved in their breeding.

In chinchillas, the presence of up to five Giardia cysts per field, observed through the method of Faust et al., is considered normal for the intestinal mucous membrane ${ }^{8}$. By using the same methodology, we found an average of 11 cysts/field. No clinical signs were observed, nor was there any relationship between the consistency 
Protozoan in captive chinchillas raised in Rio Grande do Sul, Brazil - A. C. Fagundes Gurgel et al.

Table 1. Percentage of Giardia sp., according to gender and age, in chinchillas from farms of Gravataí and Porto Alegre, State of Rio Grande do Sul, Brazil

\begin{tabular}{|c|c|c|}
\hline Variable & Number of chinchillas $(\%)$ & Positive chinchillas (\%) \\
\hline \multicolumn{3}{|c|}{ Gender } \\
\hline Females & $181(72.4)$ & $18(7.2)$ \\
\hline Males & $69(27.6)$ & $2(0.8)$ \\
\hline \multicolumn{3}{|c|}{ Age (months) } \\
\hline $0-11$ & $147(58.8)$ & $10(4)$ \\
\hline$\geq 12$ & $103(41.2)$ & $10(4)$ \\
\hline
\end{tabular}

of the feces and the presence of cysts. In this study, 181 females and 69 males were analyzed, a normal proportion for this species, since the breeding of chinchillas is based on polygamy with one male for five or six females ${ }^{3}$. When the positivity for giardiosis was compared among males and females, there was no significant difference $(p=0.07)$. A similar study conducted in dogs yielded a similar result as to the occurrence of giardiasis in male and female dogs ${ }^{17}$.

The conclusion of this study is that there is no significant difference between the two age groups ( $<12$ months and $\geq 12$ months $)(\mathrm{p}=0.47)$; nevertheless, some authors reported that Giardia sp is extremely frequent among young and confined animals18, whereas others described significant difference regarding age group in $\operatorname{dog}^{19}$.

The presence of Giardia cysts in fecal samples of chinchillas can be a source of infection to humans. Strict attention to hygiene and strong commitment to health practices are therefore very important so that the transmission of this zoonosis can be prevented.

\section{REFERENCES}

1.- NEVES D M. Criação caseira de chinchila e seu melhoramento genético. 2 ed. Nobel, 1989; pp 84-7.

2.- PESSOA C A. Vida de cão; o portal dos animais de estimação: Chinchila. Em: http:// w w w. vid a d e c a o.com.br/exotico/ index 2.asp?menu=chinchilas.htm>. Acesso em: 16 mar. 2003.

3.- SILVA J A . Manual prático de criação de chinchilas. Nobel, 1976 p 11

4.- LINDEN A R. Criação comercial de chinchilas. Guaíba: Agropecuária, 1999 p. 176.

5.- SOGAYAR M I T L, GUIMARÃES S. Giardia lamblia. In: NEVES, D. P. Parasitologia humana. 10 ed. São Paulo: Atheneu, 2000; pp107-13.

6.- OLSEN O W. Parasitología animal. I. el parasitismo y los protozoos. Aedos, 1997; p. 109.

7.- NEVES D P. Giardíase. Parasitologia dinâmica. São
Paulo: Atheneu. 2003; 23: 149-54.

8.- ALEANDRI F. Cría y Comercialización de la Chinchilla. Buenos Aires: [s.n.], 1998. pp 7-23.

9.- EIDMANN S.Untersuchungen zur Atiologie und Pathogenese von Fellscaden beim Chinchilla. Thesis (Dr. med. Vet.), Tierarztliche Hochschule Hannover, 1992. In: Giardiasis [s.l: s.n.], Cópia xerográfica.1992.

10.- FERREIRA M S, NISHIOKA S A. Criptosporidiose. In: CIMERMAN, B.; CIMERMAN, S. Parasitologia humana e seus fundamentos gerais. São Paulo: Atheneu 1999; 12: 186-9.

11.- ARACAY L, BRUZUAL E. Presencia de Cryptosporidium en ríos de Venezuela. In: Congresso Latinoamericano de Parasitología , 1991, Montevideo, Uruguay. Resumos. Montevideo 1991; 10: 247.

12.- YAMINI B, RAJU N R. Gastroenteritis associated with a Cryptosporidium sp. in a chinchilla. J Am Vet Med Assoc 1986; 189: 1158-9.

13.- SILVA N R S, CHAPLIN E L, KESSLER R H. Protozooses dos animais domésticos. Porto Alegre:UFRGS, Faculdade de Veterinária 1980; p. 92.

14.- BOUSSARIE D. Carte D' Identité Chinchilla - WSAVA 2002. Disponível em: <http://www.vin.com/ $\mathrm{p} r$ o c e e d i n g s / P r o c e e d i n g s. plx?CID=WSAVA2002\&PID=PR02570. $>$ Acesso em 1 jul 2004.

15.- URQUHART G M, ARMOUR J, DUNCAN J L, et al. Parasitologia veterinária. 2 ed. Rio de Janeiro: Guanabara Koogan 1998; 196-203.

16.- HOFFMANN R P. Diagnóstico de parasitismo veterinário. Porto Alegre: Sulina, 1987; 156 p.

17.- BECK C. Infecção por Giardia lamblia (Kunstler, 1882) em cães (Canis familiaris) determinada através do método de Faust e cols. (1939) e da técnica de coloração da auramina, no município de Canoas, RS, Brasil. 2003. 54 f. Dissertação (Mestrado em Ciências Veterinárias)-Universidade Federal do Rio Grande do Sul, Porto Alegre, RS. 2003.

18.- SHERDING R G, JOHNSON S E. Doenças dos intestinos. In: BIRCHARD, Stephen J.; SHERDING, Robert G. Manual Saunders: Clínica de Pequenos Animais. São Paulo: Roca, 1998; pp 771-803.

19.- BARTMANN A. Freqüência de Giardia lamblia (Kunstler, 1882), em cães (Canis familiaris) determinada através de exames parasitológicos solicitados por clínicas veterinárias da cidade de Porto Alegre, Rio Grande do Sul, Brasil. 2002. 80 f. Dissertação (Mestrado em Ciências Veterinárias) - Universidade Federal do Rio Grande do Sul, Porto Alegre, RS. 2002. 